\title{
Artificial Hybridizations in Five Species of Chilean Nolana (Solanaceae)
}

\author{
Rosanna Freyre ${ }^{1}$ and Amy C. Douglas \\ Department of Plant Biology, G36 Spaulding Hall, University of New Hampshire \\ Durham, NH 03824
}

\author{
Michael O. Dillon \\ Department of Botany, The Field Museum, 1400 South lake Shore Drive, \\ Chicago, IL 60605
}

Additional index words. germination, mericarps

\begin{abstract}
Reciprocal crosses, both intraspecific and interspecific, were made among five Chilean species of Nolana (Solanaceae), a genus native to western South America. With the exception of $N$. paradoxa, plants of all species used were grown from mericarps collected from wild populations. Self-pollinations were generally not successful, suggesting obligate allogamy. A total of 333 hybridizations were performed, of which 109 were intraspecific and 224 interspecific. Successful intraspecific hybridizations, as measured by formation of fruits, were produced for $N$. acuminata $(83 \%)$, N. elegans $(94 \%), N$. paradoxa $(82 \%)$, and $N$. rupicola $(\mathbf{1 0 0 \%})$, however viable hybrids were only obtained for $N$. paradoxa. Interspecific combinations resulted in over $80 \%$ fruit set, however, viable hybrid success ranged from only $1 \%$ to $5 \%$. Crosses included $N$. elegans $\times N$. paradoxa with 20 viable hybrids, $N$. paradoxa $\times$ $N$. elegans with two hybrids, $N$. paradoxa $\times N$. rupicola with seven hybrids, and $N$. rupicola $\times$ $N$. paradoxa with five hybrids. Exceptions included crosses involving $N$. aplocaryoides, with up to $20 \%$ fruit set. Also, the combination $N$. paradoxa $\times N$. aplocaryoides with five hybrids, had a $26 \%$ success. All interspecific hybrids obtained had $N$. paradoxa as one of the parents, which could be related to artificial selection for high germination frequency.
\end{abstract}

The genus Nolana L.f. (Solanaceae) was originally described by Linnaeus in 1762 and derives its name from the Latin, nola or small bell. Johnston (1936) in the first modern monograph, described 63 species. The most recent monograph (Mesa, 1981) reduced most species to synonyms, accepting only 18 species. However, this concept was later broadened, accepting 70 species (Mesa, 1997; Mesa et al., 1998). The genus currently consists of 85 species from Peru (38 species) and Chile (42 species), four species found in both Chile and Peru, and one species endemic to the Galápagos Islands (Dillon, in press; Dillon, et al., 2003). Most species (about 70 species) occupy fogdependent, coastal environments called lomas formations that occur from $8^{\circ}$ to $30^{\circ} \mathrm{S}$ latitude and generally within $25 \mathrm{kms}$ of the Pacific Ocean (Dillon, 1997; Dillon and Hoffmann, 1997; Rundel et al., 1991).

The genus Nolana is considered monophyletic and is diagnosed by possessing unusual sclerified fruits called mericarps, a unique

Received for publication 18 June 2004. Accepted for publication 28 Sept. 2004. This is Scientific Contribution Number 2239 from the Hew Hampshire Agricultural Experiment Station. MOD would like to acknowledge support the National Geographic Society and National Science Foundation for support of field studies. Chilean field collaborators are acknowledged and include M. Finger, J. Guerra, B. Palma, C. Trujillo, S. Teillier, and M. Villarroel. M. Nakazawa and J. Wen are thanked for molecular sequencing data and discussions of putative relationships. F. Barrie, G. Crow, and T. Davis are thanked for reading an early version of the manuscript.

${ }^{1}$ To whom reprint requests should be addressed; e-mail rf@unh.edu. described as N. tenella Lindley (Saunders, 1934; Johnston, 1936). Nolana tenella was also produced by artificial hybridizations between $N$. humifusa $\times N$. paradoxa (Saunders, 1934). To our knowledge, $N$. tenella was never widely cultivated nor available commercially.

For the present study, we germinated mericarps and obtained plants of five endemic Chilean Nolana species: N. acuminata (Miers) Miers ex Dunal,N. aplocaryoides (Gaudichaud) I.M. Johnston, N. elegans (Philippi) Reiche, $N$. paradoxa Lindley, and $N$. rupicola Gaudichaud. As far as we are aware this may have been the first time that these species (with the exception of cultivated $N$. paradoxa) were grown in greenhouse conditions in the U.S. The objectives of our study were to 1) provide an updated description of these five Chilean Nolana species based on herbarium material collected in the field in 1998 by one of us (Dillon) and corroborated by our greenhouse-grown plants and 2) attempt hybridizations between these species.

\section{Materials and Methods}

Plantmaterial. Mericarps from four Chilean endemic Nolana species ( $N$. acuminata, $N$. aplocaryoides, $N$. elegans, $N$. rupicola) were collected with herbarium material in 1988 and stored at room temperature. We attempted germination of $>2000$ mericarps at the University of New Hampshire (UNH) in 2001, obtaining a total of eight plants of $N$. acuminata, six plants of $N$. aplocaryoides, seven plants of N. elegans, and three plants of $N$. rupicola. Additionally, seven plants of $N$. paradoxa (originally from Chile) were selected from sown mericarps of 'Blue Bird' and 'Snowbird' from Thompson \& Morgan Seedsmen, Inc. (Jackson, N.J.), and from 'Cliff Hanger Blue' and 'Cliff Hanger White' from Grimes Seed Inc. (Concord, Ohio). Breeding line NL02-14 is a selection from an $\mathrm{F}_{1}$ of $N$. paradoxa 'Bluebird' $\times$ 'Snowbird' and NL03-5 is a selection from the reciprocal cross. Both $F_{1}$ hybrids were selected from populations sown at UNH in February 2001.

Between one to five accessions for each Nolana species were selected as parental lines based on plants' overall vigor and appearance, while 10 breeding lines of $N$. paradoxa were used. Average corolla diameter and flower color for each parental line were determined $1 \mathrm{~d}$ after bud opening. Corolla diameter was determined by measuring five flowers for each plant while colors of the corolla and outer and central portions of the flower throat were determined using the Royal Horticultural Society Colour Chart (1995).

All Nolana plants were maintained in 25$\mathrm{cm}$ pots at UNH using 560 Scotts coir soiless media (The Scotts Co., Marysville, Ohio) in a greenhouse with $21{ }^{\circ} \mathrm{C}$ day/ $18{ }^{\circ} \mathrm{C}$ night setpoints. Fertilization was constant with a $20 \mathrm{~N}-4.3 \mathrm{P}-16.7 \mathrm{~K}$ fertilizer at a maximum 150 $\mathrm{mg} \cdot \mathrm{L}^{-1} \mathrm{~N}$. For healthy growth, the growing medium $\mathrm{pH}$ was maintained between 5.7 to 6.3 and electroconductivity between 1.0 to $2.0 \mathrm{mS} \cdot \mathrm{cm}^{-1}$. Plants were pruned regularly and propagated vegetatively by tip cuttings when needed.

Hybridizations. As many combinations of crosses as possible between parental lines were 

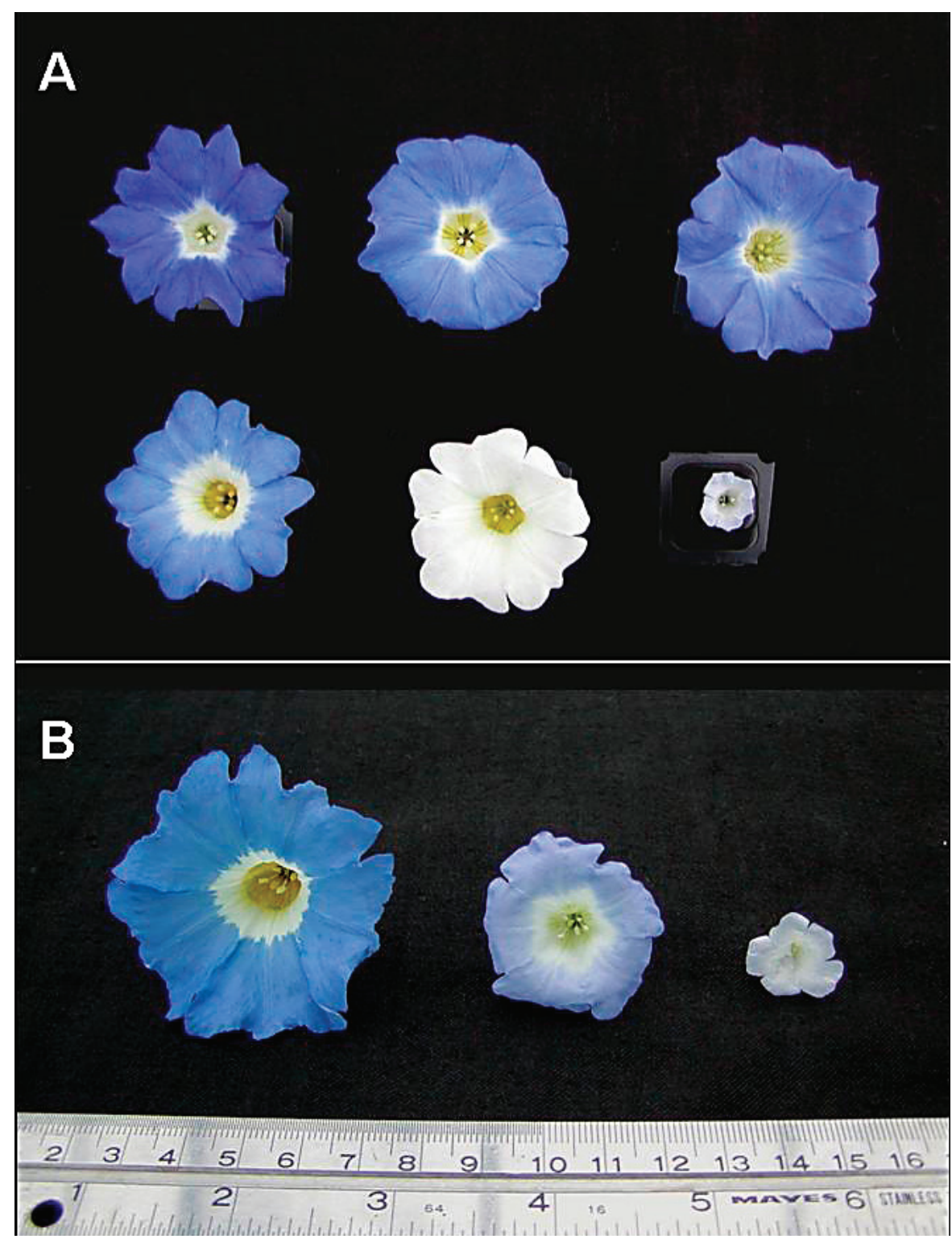

Fig. 1. (A) Nolana corollas for five Chilean species: N. acuminata, N. elegans, $N$. rupicola (top row, left to right); N. paradoxa 'Bluebird', N. paradoxa 'Snowbird', and N. aplocaryoides (bottom row, left to right). (B) Nolana paradoxa corolla (left), $\mathrm{F}$, hybrid corolla (center), $N$. aplocaryoides corolla (right). Additional color figures can be seen at http://www.sacha.org/Nolana/HortScience.htm

made given flowernumbers and differing stages of floral development, pollinating up to three different flowers for each cross. For practical reasons, pollinations were performed and mericarps harvested as two groups, one in Augustand the other in September 2001. One day before anthesis, buds were emasculated by pulling out the corolla tube along with the attached anthers. They were immediately pollinated with fresh pollen and tagged for identification. Mericarps were harvested individually when the sepals turned slightly yellow and visible mericarps were a dark brown color. For the first group of crosses, the number of mericarps in each gynoecium was counted, while for the second group of crosses the mericarps were bulked and total number counted.

Germination of mericarps. Mericarps obtained for each cross were sown in November 2001 in seed trays with 360 Scotts coir media (The Scotts Co., Marysville, Ohio). These were placed on a germinating bench with a Biotherm Heat Mat (Trueleaf Technologies, Winnetka, CA) holding soil temperature at an average 23 ${ }^{\circ} \mathrm{C}$, and irrigated with an overhead Solar3B Mist Controller (Davis Engineering, Cotati, Calif.) with set point of $10 \mathrm{~s}$ on time, repeat interval of 24 solar units, night time repeat interval of 30 min. During a period of 8 weeks, seed trays were checked three times per week. Upon emergence, seedlings were transplanted into cell trays and later into $15-\mathrm{cm}$ pots. Twenty mericarps each of 'Snowbird', 'Cliff Hanger Blue', and 'Cliff Hanger White' were included for comparison against wild lines and hybrids.

\section{Results and Discussion}

Nolana wild accessions. Germination of mericarps of Nolana wild species collected in Chile was $<1 \%$, which could be mostly due to the fact that they had been collected several years earlier and had not been stored under ideal conditions. A total of 24 plants of four different Nolana wild species (N. acuminata, $N$. aplocaryoides, $N$. elegans, and $N$. rupicola) were obtained from mericarps germinated at UNH. As far as we aware, this is the first time these species have been grown under greenhouse conditions. Greenhouse-grown plants had very vigorous growth, with larger leaves and flowers than those found in the wild. Nolana acuminata and $N$. aplocaryoides are annual herbs, whereas $N$. elegans and $N$. rupicola are perennials that die during the dry season under natural conditions in lomas formations. However, with unlimited water supply in the greenhouse, plants of all four species did not senesce but behaved like perennials with continuous growth and flowering.

Flowers from the four wild Nolana species and cultivated $N$. paradoxa can be seen in Fig. 1A. There was no significant morphological variation within each species of $N$. acuminata, $N$. aplocaryoides and $N$. rupicola, although some plants appeared more vigorous and were therefore selected for hybridizations. In two accessions of $N$. elegans (051-4 and 051-6) some of the flowers had split corollas rather than petals fused into a tube, which is characteristic of the genus. This trait was present in approximately two thirds of all flowers in each plant. We have never observed this floral anomaly in this or any other Nolana species either in the field or on herbarium specimens. We are currently using these two accessions to develop breeding populations and gain insight into the inheritance and genetics of this trait.

Species' descriptions and relationships. The distribution and salient morphological characters of the five Chilean Nolana species used in this study is provided in Table 1. Nolana acuminata, N. elegans, N. paradoxa, and N. rupicola are all morphologically similar. They are all annual to perennial herbs with basal rosettes of leaves arising from a thick taproot, stems are generally prostrate to decumbent, the relatively large flowers are sessile in the leaf axils, the calyx lobes are symmetrical, the corollas are blue to lavender, and 10 to 20 mericarps are borne in two series. Overall, $N$. acuminata is most similar in appearance to $N$. rupicola; however, it is generally smaller, and typically grows at higher altitudes, further from the ocean. Nolana rupicola is a coarser plant with large flowers, tending to grow in near-ocean environments. The leaf bases in N. acuminata are not rounded as in N. rupicola, but, instead, are abruptly short-decurrent on the stems. The individual mericarps of $N$. rupicola are indistinguishable from those of $N$. acuminata. Nolana elegans most closely resembles $N$. rupicola, and is also morphologically similar to $N$. acuminata and $N$. paradoxa. It is readily distinguished from all these species by possessing a dark central spot in the proximal portion of the corolla, and leaf bases that are clearly obliquely decurrent on the stems. Nolana paradoxa is the species in this study with the most southern distribution, and is found in sandy, near seashore environments. It is distinguished from the other species in that it has five pronounced green spots in the throat of the corolla. All-white forms are present in low frequencies in N. acuminata, N. paradoxa 
and N. rupicola. Nolana aplocaryoides is very morphologically distinct from the other Chilean species utilized in this study. Rather than having a basal rosette as the other four species, it has one main stem and branched, erect to ascending secondary stems. Leaves are small and highly succulent, covered with hairs. Flowers are small and light lavender to white.

A full phylogeny for Nolana has yet to be completed, but several monophyletic groups have been suggested by morphological and molecular analyses (Tago-Nakawaza and Dillon, 2000). Three large clades have been identified. The well-marked acuminata group is sister to a large clade composed primarily of Chilean endemics, and these two clades are basal and sister to a diverse group of primarily Peruvian endemics. In this study, four of the five species $-N$. acuminata, $N$. elegans, $N$. paradoxa, and N. rupicola - are members of the acuminata group. Nolana aplocaryoides is placed in the previously mentioned clade of Chilean endemics, and not a member of the acuminata group.

Intraspecific and interspecific hybridizations. Breeding lines of N. paradoxa and accessions of different Nolana species used for hybridizations are shown in Table 2. Accessions are labeled according to the matching code from their corresponding herbarium voucher held at the Field Museum in Chicago (F). Three selfpollinations were performed on each of two accessions of $N$. acuminata, N. elegans and $N$. rupicola (data not shown). Fruit formed only on one accession of $N$. elegans and in both accessions of $N$. rupicola, however none of the mericarps germinated. Self-pollination data was therefore not included in this study. Three flowers were pollinated for each combination of intraspecific and interspecific crosses with the exception of four crosses where only one flower was pollinated, and one cross where two flowers were pollinated. Overall, fewer crosses were made involving $N$. acuminata and $N$. aplocaryoides. Accessions of $N$. acuminata had

Table 1. Distribution and morphological description of five Chilean endemic Nolana species.

\begin{tabular}{|c|c|c|c|c|c|}
\hline Parameter & N. acuminata & N. aplocaryoides & N. elegans & N. paradoxa & N. rupicola \\
\hline Distribution & $\begin{array}{l}\text { Northern to central } \\
\text { coastal Chile } \\
\left(23^{\circ} 33^{\prime} \mathrm{S}-33^{\circ} 00^{\prime} \mathrm{S}\right) \\
0-900 \text { masl }\end{array}$ & $\begin{array}{l}\text { Northern to north-central } \\
\text { coastal Chile } \\
\left(23^{\circ} 39^{\prime} \mathrm{S}-27^{\circ} 04^{\prime} \mathrm{S}\right) \\
0-500 \text { masl }\end{array}$ & $\begin{array}{l}\text { Northern coastal Chile } \\
\left(22^{\circ} 05^{\prime} \mathrm{S}-27^{\circ} 00^{\prime} \mathrm{S}\right) \\
0-500 \text { masl }\end{array}$ & $\begin{array}{l}\text { Central to southern } \\
\text { coastal Chile } \\
\left(32^{\circ} 45^{\prime} \mathrm{S}-42^{\circ} 40^{\prime} \mathrm{S}\right) \\
0-100 \text { masl }\end{array}$ & $\begin{array}{l}\text { Northern to north-central } \\
\text { coastal Chile } \\
\left(23^{\circ} 30^{\prime} \mathrm{S}-26^{\circ} 32^{\prime} \mathrm{S}\right) \\
0-500 \text { masl }\end{array}$ \\
\hline Basal rosette & $\begin{array}{l}\text { Lanceolate leaves, } \\
\text { up to } 12 \mathrm{~cm} \text { long, } \\
4 \mathrm{~cm} \text { wide }\end{array}$ & $\begin{array}{l}\text { None, one } \\
\text { main stem }\end{array}$ & $\begin{array}{l}\text { Lanceolate to } \\
\text { spathulate } \\
\text { leaves }\end{array}$ & $\begin{array}{l}\text { Lanceolate to } \\
\text { spathulate } \\
\text { leaves }\end{array}$ & $\begin{array}{l}\text { Well developed } \\
\text { leaves up to } \\
15 \mathrm{~cm} \text { long }\end{array}$ \\
\hline Stems & $\begin{array}{l}\text { Prostrate to erect, } \\
\text { flexulose }\end{array}$ & $\begin{array}{l}\text { Erect to ascending, } \\
\text { to } 50 \mathrm{~cm} \text { tall, } \\
\text { usually branched }\end{array}$ & $\begin{array}{l}\text { Ascending to } \\
\text { decumbent }\end{array}$ & Decumbent & Decumbent \\
\hline Pubescence & $\begin{array}{l}\text { Dense, multi-cellular } \\
\text { trichomes }\end{array}$ & $\begin{array}{l}\text { Clammy, simple } \\
\text { spreading hairs }\end{array}$ & $\begin{array}{l}\text { Multicellular, } \\
\text { nonglandular } \\
\text { trichomes }\end{array}$ & $\begin{array}{l}\text { Flaccid stipitate } \\
\text { - glandular trichomes, } \\
\text { enlarged bases }\end{array}$ & $\begin{array}{l}\text { Flaccid stipitate } \\
\text {-glandular trichomes }\end{array}$ \\
\hline Cauline leaves & $\begin{array}{l}\text { Bases obliquely } \\
\text { decurrent }\end{array}$ & $\begin{array}{l}\text { Narrowly oblong } \\
\text { to elliptic, } \\
\text { highly succulent }\end{array}$ & $\begin{array}{l}\text { Bases clearly } \\
\text { obliquely decurrent } \\
\text { on the stems }\end{array}$ & $\begin{array}{l}\text { Bases narrowed } \\
\text { to a petiole; not } \\
\text { decurrent on stems }\end{array}$ & $\begin{array}{l}\text { Lanceolate to broadly } \\
\text { ovate, auriculate to } \\
\text { sessile, not decurrent }\end{array}$ \\
\hline Corolla & $\begin{array}{l}\text { Funneliform, } \\
\text { color variable, } \\
\text { light to deep blue, } \\
\text { white throat }\end{array}$ & $\begin{array}{l}\text { Small, light } \\
\text { lavender to white }\end{array}$ & $\begin{array}{l}\text { Dark blue, } \\
\text { white-yellow throat, } \\
\text { dark purple inner } \\
\text { or proximal spot }\end{array}$ & $\begin{array}{l}\text { Lavender to blue, } \\
\text { white central band, } \\
\text { yellow throat with } \\
5 \text { pronounced green spots }\end{array}$ & $\begin{array}{l}\text { Large, deep } \\
\text { purple or blue, } \\
\text { white-yellow throat }\end{array}$ \\
\hline Stamen filaments & $\begin{array}{l}\text { Purple, pubescent } \\
\text { at the base }\end{array}$ & White & White & White & White \\
\hline Anther theca & $\begin{array}{l}\text { White } \\
10-15 \text { in two series }\end{array}$ & $\begin{array}{l}\text { White } \\
3-5 \text { in a single series }\end{array}$ & $\begin{array}{l}\text { White } \\
10-15 \text { in two series }\end{array}$ & $\begin{array}{l}\text { White } \\
\text { about } 10 \text { two series }\end{array}$ & $\begin{array}{l}\text { White } \\
10-15 \text { in two series }\end{array}$ \\
\hline
\end{tabular}

Table 2. Species names, vouchers, University of New hampshire (UNH) codes, cultivar names, and sources or collection localities of Nolana material used for artificial hybridizations.

\begin{tabular}{|c|c|c|c|c|c|c|c|}
\hline Species & $\begin{array}{l}\text { Source } \\
\text { and } \\
\text { location }\end{array}$ & $\begin{array}{l}\text { Herbarium } \\
\text { voucher }^{2}\end{array}$ & Cultivar $^{y}$ & $\begin{array}{l}\text { UNH } \\
\operatorname{codes}^{x}\end{array}$ & $\begin{array}{l}\text { Avg } \\
\text { corolla } \\
\text { diam } \\
(\mathrm{cm})\end{array}$ & $\begin{array}{l}\text { Corolla } \\
\text { color }\end{array}$ & $\begin{array}{l}\text { Throat color } \\
\text { (outer portion/ } \\
\text { central portion) }\end{array}$ \\
\hline N. acuminata & $\begin{array}{l}\text { Chile, Atacama, } \\
\text { Prov. Chañaral, } \\
\text { Las Lomitas, } 1997\end{array}$ & $\begin{array}{l}\text { Dillon and Trujillo } \\
8014\end{array}$ & & $\begin{array}{l}\text { 014-3, 014-5, } \\
014-7\end{array}$ & 5.0 & $2-89 \mathrm{~B}$ & white/1-4D \\
\hline N. aplocaryoides & $\begin{array}{r}\text { Chile, Prov. Antofagasta, } \\
10 \mathrm{~km} \text { N of Taltal,1997 }\end{array}$ & $\begin{array}{l}\text { Dillon and Villarroel } \\
8145\end{array}$ & & $145-1$ & 1.2 & $2-91 \mathrm{C}$ & white \\
\hline N. elegans & $\begin{array}{l}\text { Chile, Prov. Antofagasta, } \\
\text { Cerro Perales, } 1997\end{array}$ & $\begin{array}{l}\text { Dillon and Trujillo } \\
8051\end{array}$ & & $\begin{array}{l}051-2,051-3,051-4 \text {, } \\
051-6,051-7\end{array}$ & 4.5 & $2-95 B$ & white/1-5A \\
\hline N. paradoxa & Commercial seed ${ }^{x}$ & NA & 'Bluebird' & $\begin{array}{l}\text { BB1, BB2, } \\
\text { BB3 }\end{array}$ & $\begin{array}{l}4.2,4.2 \\
4.1\end{array}$ & $\begin{array}{l}\text { 2-96B, 2-95C, } \\
2-87 \mathrm{C}\end{array}$ & $\begin{array}{l}\text { white/1-12B, white/1-5C, } \\
\text { white/1-12B }\end{array}$ \\
\hline \multicolumn{8}{|l|}{ N. paradoxa } \\
\hline & Commercial seed & NA & 'Snowbird' & SB1 & 4.3 & white & white/1-12B \\
\hline N. paradoxa & Commercial seed & NA & 'Cliff Hanger Blue' & $\mathrm{CB} 1, \mathrm{CB} 2, \mathrm{CB} 3$ & $\begin{array}{l}3.8,3.8 \\
\quad 4.8\end{array}$ & $\begin{array}{l}\text { 2-94B, 2-96C, } \\
2-96 \mathrm{C}\end{array}$ & $\begin{array}{l}\text { white/1-5C, white/1-5B, } \\
\text { white/1-12B }\end{array}$ \\
\hline N. paradoxa & Commercial seed & NA & 'Cliff Hanger White' & CW1 & 4.2 & white & white/1-12B \\
\hline N. paradoxa & $\mathrm{BB} 1 \times \mathrm{SB} 1 \mathrm{~F}_{1}$ hybrid & NA & & NL02-14 & 4.7 & $2-96 \mathrm{C}$ & white/1-12B \\
\hline N. paradoxa & $\mathrm{SB} 1 \times \mathrm{BB} 1 \mathrm{~F}_{1}$ hybrid & NA & & NL03-5 & 3.2 & $2-96 \mathrm{~B}$ & white/1-5B \\
\hline N. rupicola & $\begin{array}{l}\text { Chile, Atacama, } \\
\text { Prov. Chañaral, } \\
\text { Las Lomitas, } 1997\end{array}$ & $\begin{array}{l}\text { Dillon and Trujillo } \\
8005\end{array}$ & & $005-1,005-2$ & 6.3 & $2-94 \mathrm{~A}$ & white/1-4C \\
\hline
\end{tabular}

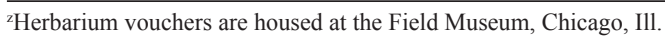

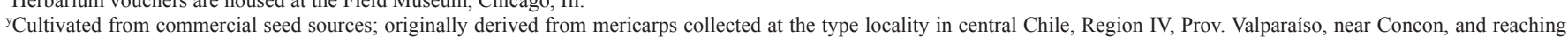
England in 1822.

${ }^{\mathrm{x}}$ Codes used for breeding lines housed in the University of New Hampshire Research Greenhouses. 
Table 3. Average number of days to fruit harvest and number of mericarps per gynoecium for the first group of hybridizations in Nolana.

\begin{tabular}{|c|c|c|c|c|c|c|}
\hline \multirow[b]{2}{*}{ Female } & \multicolumn{6}{|c|}{ Male } \\
\hline & $\begin{array}{l}\text { N. acuminata } \\
(2)^{\mathrm{z}}\end{array}$ & $\begin{array}{c}\text { N. aplocaryoides } \\
\text { (1) }\end{array}$ & $\begin{array}{l}\text { N. elegans } \\
\text { (4) }\end{array}$ & $\begin{array}{c}\text { N. paradoxa } \\
(6)\end{array}$ & $\begin{array}{l}\text { N. rupicola } \\
\text { (1) }\end{array}$ & Avg \\
\hline N. acuminata (2) & $34(20 \pm 3.8)^{y}$ & 0 & $33(26 \pm 4.2)$ & $36(22 \pm 7.5)$ & --- & $35(23 \pm 5.9)$ \\
\hline N. aplocaryoides (1) & 0 & --- & -- & -- & 0 & 0 \\
\hline N. elegans (4) & --- & --- & $36(15 \pm 3.0)$ & $38(14 \pm 4.9)$ & $34(14 \pm 3.5)$ & $37(14 \pm 4.2)$ \\
\hline N. paradoxa $(10)$ & $38(19 \pm 2.7)$ & $50(7 \pm 0.7)$ & $35(15 \pm 3.5)$ & $44(15 \pm 4.5)$ & $45(18 \pm 3.1)$ & $43(15 \pm 4.5)$ \\
\hline N. rupicola $(1)$ & $30(15 \pm 2.3)$ & --- & $36(12 \pm 4.7)$ & $36(16 \pm 2.5)$ & --- & $32(13 \pm 4.1)$ \\
\hline
\end{tabular}

${ }^{\mathrm{z} N u m b e r}$ of different accession used as parents.

${ }^{y}$ Average number of days to fruit harvest (average number of mericarps per gynoecium \pm standard deviation).

weak growth in the greenhouse and few flowers, while $N$. aplocaryoides developed slowly and flowered later, producing very small flowers that were harder to pollinate.

Days to harvest and number of mericarps per gynoecium for the first group of crosses is shown in Table 3 . In this group of crosses, the combination $N$. aplocaryoides $\times N$. rupicola, and $N$. aplocaryoides $\times N$. acuminata and its reciprocal were not successful. For successful combinations, fruits required at least 30 days after pollination to be ready to harvest. If fruits were allowed to dry completely, mericarps became detached from the placenta and dropped from the open gynoecium. In general, crosses involving $N$. paradoxa crosses required a longer period for fruit maturity, with the cross with $N$. aplocaryoides requiring up to 50 days. The number of mericarps produced per fruit averaged 14 per gynoecium for $N$. elegans, $N$. paradoxa and $N$. rupicola, while $N$. acuminata had over 20 mericarps per fruit. There were no apparent differences in number of mericarps per fruit between intraspecific and interspecific hybridizations. One exception was the cross between $N$. paradoxa and $N$. aplocaryoides, with an average of only 7 mericarps per gynoecium, which could be explained by reduced compatibility of this cross.

Combining both sets of crosses, a total of 333 hybridizations were performed, of which 109 were intraspecific and 224 interspecific. Total number of hybridizations made and fruits obtained are shown in Table 4. For intraspecific hybridizations, fruit set was $83 \%$ for $N$. acuminata, $94 \%$ for $N$. elegans, $82 \%$ for $N$. paradoxa, and $100 \%$ for $N$. rupicola. In regards to interspecific hybridizations, fruit set was $100 \%$ for crosses between $N$. elegans $\times N$. acuminata, $N$. elegans $\times$ rupicola, $N$. rupicola $\times$ $N$. acuminata, $N$. rupicola $\times N$. elegans, and $N$. rupicola $\times N$. paradoxa. Fruit set was between $86 \%$ to $93 \%$ for $N$. acuminata $\times N$. elegans, $N$. elegans $\times N$. paradoxa, $N$. paradoxa $\times N$. acuminata, and $N$. paradoxa $\times N$. elegans, and $N$. paradoxa $\times N$. rupicola, and only around $50 \%$ for $N$. acuminata $\times N$. paradoxa. Hybridizations using $N$. aplocaryoides as a female were not successful, and fruit set was $<20 \%$ when it was used as a male in crosses with $N$. paradoxa and $N$. rupicola.

Total number of mericarps per cross and number of hybrids obtained are shown in Table 5. Total number of mericarps obtained was 3993 , of which 1498 and 1835 were from intraspecific and interspecific crosses, respectively. A total of 98 viable hybrids were obtained from intraspecific crosses, while 39 hybrids were obtained from interspecific crosses. On aver- age, survival rates of germinating seedlings ranged between $67 \%$ to $100 \%$ (data not shown). Surprisingly, there was no germination from intraspecific hybridizations between accessions of $N$. acuminata, $N$. elegans or $N$. rupicola, in spite of the number of mericarps obtained ( 305 , 216 and 132, respectively). In comparison, the success rate for intraspecific hybridizations between cultivars of $N$. paradoxa was $12 \%$ (98 seedlings from 845 mericarps), and the success rate of control cultivars N. paradoxa 'Snowbird', 'Cliff Hanger Blue' and 'Cliff Hanger White' averaged $43 \%$.

With regard to interspecific hybridizations, although there were in many cases a large number of mericarps per combination, few viable hybrids were obtained. Successful combination of species were $N$. elegans $\times N$. paradoxa with 20 hybrid offspring, $N$. paradoxa $\times N$. aplocaryoides with 5 hybrids, $N$. paradoxa $\times$ $N$. elegans with 2 hybrids, $N$. paradoxa $\times N$. rupicola with 7 hybrids, and $N$. rupicola $\times N$. paradoxa with 5 hybrids. Success rate ranged from $1 \%$ to $5 \%$ with the exception of $26 \%$ for $N$. paradoxa $\times N$. aplocaryoides. It is noteworthy that all interspecific hybrids resuted from crosses that included cultivated $N$. paradoxa as one of the parents. This may be indicative of artificial selection of $N$. paradoxa during cultivation for increased germination success.

Reasons for very low or lack of germination of mericarps obtained may be several. First, we observed some mericarps that appeared to be misshapen or hollow, indicating that although

Table 4. Total number of crosses performed and number of fruits obtained in artificial hybridizations in Nolana.

\begin{tabular}{lccccc}
\hline & \multicolumn{5}{c}{ Male } \\
\cline { 2 - 6 } Female & $\begin{array}{c}\text { N. acuminata } \\
(3)^{\mathrm{z}}\end{array}$ & $\begin{array}{c}\text { N. aplocaryoides } \\
(1)\end{array}$ & $\begin{array}{c}\text { N. elegans } \\
(5)\end{array}$ & $\begin{array}{c}\text { N. paradoxa } \\
(9)\end{array}$ & $\begin{array}{c}\text { N. rupicola } \\
(2)\end{array}$ \\
\hline N. acuminata $(3)$ & $10 / 12(83 \%)^{\mathrm{y}}$ & $0 / 6$ & $8 / 9(89 \%)$ & $11 / 21(52 \%)$ & $0 / 7$ \\
N. aplocaryoides $(1)$ & $0 / 4$ & -- & $0 / 3$ & $0 / 6$ & $0 / 3$ \\
N. elegans $(5)$ & $3 / 3(100 \%)$ & $0 / 3$ & $17 / 18(94 \%)$ & $27 / 30(90 \%)$ & $12 / 12(100 \%)$ \\
N. paradoxa $(10)$ & $22 / 24(92 \%)$ & $3 / 16(19 \%)$ & $18 / 21(86 \%)$ & $55 / 67(82 \%)$ & $14 / 15(93 \%)$ \\
N. rupicola $(2)$ & $6 / 6(100 \%)$ & $1 / 6(17 \%)$ & $12 / 12(100 \%)$ & $21 / 21(100 \%)$ & $12 / 12(100 \%)$ \\
\hline
\end{tabular}

${ }^{\mathrm{z}}$ Number of accession used as parents.

${ }^{y}$ Number of fruit/number of crosses (percentage).

Table 5. Total number of mericarps and viable hybrids obtained in artificial hybridizations in Nolana.

\begin{tabular}{lccccc}
\hline & \multicolumn{5}{c}{ Male } \\
\cline { 2 - 6 } Female & $\begin{array}{c}\text { N. acuminata } \\
(3)^{\mathrm{z}}\end{array}$ & $\begin{array}{c}\text { N. aplocaryoides } \\
(1)\end{array}$ & $\begin{array}{c}\text { N. elegans } \\
(5)\end{array}$ & $\begin{array}{c}\text { N. paradoxa } \\
(9)\end{array}$ & $\begin{array}{c}\text { N. rupicola } \\
(2)\end{array}$ \\
\hline N. acuminata (3) & $0 / 305^{\mathrm{y}}$ & $0 / 0$ & $0 / 217$ & $0 / 288$ & $0 / 61$ \\
N. aplocaryoides $(1)$ & $0 / 0$ & --- & $0 / 0$ & $0 / 0$ & $0 / 0$ \\
N. elegans $(5)$ & $0 / 47$ & $0 / 0$ & $0 / 216$ & $20 / 374(5 \%)$ & $0 / 178$ \\
N. paradoxa $(10)$ & $0 / 326$ & $5 / 19(26 \%)$ & $2 / 288(1 \%)$ & $98 / 845(12 \%)$ & $7 / 225(3 \%)$ \\
N. rupicola $(2)$ & $0 / 64$ & $0 / 6$ & $0 / 129$ & $5 / 273(2 \%)$ & $0 / 132$ \\
\hline
\end{tabular}

${ }^{\mathrm{z}}$ Number of accession used as parents.

${ }^{y}$ Number of hybrids/number of mericarps sown (percentage). mericarps may have formed, embryos did not. Second, seed dormancy in wild species may be present, whereas cultivars of $N$. paradoxa may have been selected for increased germination rates under cultivated conditions. Mericarps may remain dormant for many years in natural conditions in lomas formations. It is interesting to note that during exceptionally strong El Niño conditions of 1982-83 and 1997-98, it rained in hyper-arid areas in Peru and Chile (Dillon and Rundel, 1990; Dillon et al., 2003). This resulted in population booms of Nolana species extending over very large areas, due to germination of mericarps that had possibly lain dormant for 15 years or more. For further studies, dissection of mature mericarps to determine if embryos are present would be a good diagnostic tool to elucidate whether low germination rates are mostly due to inviable embryos, seed dormancy or both factors. If embryos appear to be viable, additional studwould be required to break seed dormancy and determine best germination treatments for lana species under cultivation. by Saunders (1934). This study resulted in the creation of $\mathrm{F}_{1}$ hybrids between $N$. humifusa $\times$ $N$. paradoxa and the reciprocal cross. Saunders observed that both species were readily self-fertile, a result we have not been able to duplicate for any of the species in this study. The large conspicuous flowers with well-developed nectaries and frequent visitation by insects in reproductive biology of Nolana was conducted 
field conditions may be indicative of allogamy in Nolana. Our preliminary studies indicate the possibility of self-incompatibility mechanisms, but further studies need to be conducted.

Nolana species are often encountered growing sympatrically in natural populations, but over 20 years of field observations by one of us (Dillon) have not detected putative natural hybrids. This suggests that the observed sympatry is secondary and likely connected with historical fluctuations in climate and resulting ecological shifts. Artificial interspecific hybrids have previously been reported between two, quite distantly related species, $N$. humifusa, a northern Peruvian endemic, and N. paradoxa, a central to southern Chilean endemic (Johnston, 1936; Saunders, 1934). In the present study, a selection of Chilean endemic species were crossed, some of which have overlapping geographic distributions, but generally occupying different ecological niches, i.e., $N$. acuminata, $N$. elegans and $N$. rupicola all occur in northern Chile, but seldom actually sympatrically. Some of our hybridizations between species were successful, to the extent that we obtained viable $F_{1}$ hybrids. However, fertility of these hybrids still needs to be evaluated. If the hybrids are fertile and can produce offspring, it would suggest that the development of interspecific breeding barriers was not likely involved in the original speciation events; rather, that speciation was allopatric based upon geographic and/or ecological isolation.

As mentioned previously, four of the species, N. acuminata, N. elegans, $N$. paradoxa, and $N$. rupicola, are considered closely related by both morphological criteria and molecular sequence data (Tago-Nakazawa and Dillon, 2000; Wen and Dillon, unpublished data). The artificial hybrids in this group are not particularly distinctive, since the parents closely resemble each other in this complex. The successful crosses and resulting hybrids involving $N$. aplocaryoides are more noteworthy. This species is not considered closely related to any of the other species used in this study. Nolana aplo- caryoides and N. paradoxa are geographically isolated, with natural distributions separated by $600 \mathrm{~km}$. Attempted hybridizations using $N$. aplocaryoides as a female parent were not successful. However, five $N$. paradoxa $\times N$. aplocaryoides $\mathrm{F}_{1}$ hybrids were obtained, and these were generally intermediate in both vegetative and floral characteristics. Seedlings had one main stem like $N$. aplocaryoides, but branches were decumbent to prostrate rather than erect, more similar to $N$. paradoxa. The leaf size and shape was intermediate to the parents, but the pubescence was dense, of long trichomes, and typical of $N$. aplocaryoides. Corolla size, shape, and coloration were intermediate (Fig. 1B), and the yellow proximal throat was present in the $\mathrm{F}_{1}$, but not as well-differentiated as in N. paradoxa.

All interspecific hybrids and a selection of $N$. paradoxa intraspecific hybrids were vegetatively propagated and grown in a replicated field trial in Summer 2002 at UNH. Several hybrids had different flower color and growth habit than existing commercial cultivars of $N$. paradoxa, and some of them had superior vigor and flowering. Currently the best performing interspecific $\mathrm{F}_{1}$ hybrids are in commercial evaluation trials to determine if they have potential as new cultivars for the vegetatively propagated market. Potentially, Nolana hybrids could be particularly valuable flowering garden plants, especially in dry areas with limited rainfall. Furthermore, sterile interspecific hybrids are of special interest to avoid problems of invasiveness of this exotic plant.

\section{Literature Cited}

Bondeson, W.E. 1896. Gynoecial morphology and funicular germination plugs in the Nolanaceae. Nord. J. Bot. 6:183-198.

Datta, S. 1933. Embryological and cytological studies in Nolana atriplicifolia and N. prostrata. J. Ind. Bot. Soc. 12:131-152.

Di Fulvio, T.E. 1969. Embriología de Nolana paradoxa (Nolanaceae). Kurtiziana 5:39-54.

Dillon, M.O. in press. Nolanaceae. In: K. Kubitzki (ed.). The families and genera of vascular plants.
Springer Verlag, Berlin.

Dillon, M.O. 1997. Lomas Formations-Peru. pp. 519-527. In: S.D Davis, V.H. Heywood, O. Herrera-McBryde, J.Villa-Lobos, andA.C. Hamilton (eds.). WWF Info. Press, Oxford, U.K.

Dillon, M.O. and A.E. Hoffmann-J. 1997. Lomas Formations of the Atacama Desert, Northern Chile. Pp. 528-535. In: S.D Davis, V.H. Heywood, O. Herrera-McBryde, J. Villa-Lobos, and A.C. Hamilton (eds.). Centres of plant diversity, a guide and strategy for their conservation. WWF Info. Press, Oxford, U.K.

Dillon, M.O., M. Nakazawa, and S. Leiva. 2003. The Lomas Formations of Coastal Peru: Composition and Biogeographic History, p. 1-9. In: J. Haas and M.O. Dillon (eds.). El Niño in Peru: Biology and culture over 10,000 years. Fieldiana: Botany. N.S. 43. publ. 1524.

Dillon, M.O. and P.W. Rundel. 1990. The botanical response of the Atacama and Peruvian Desert flora to the 1982-83 ElNiño event, p. 487-504. In: P.W. Glynn (ed.). Global ecological consequences of the 1982-83 ElNiño southern oscillation. Elsevier Science Publishers, New York.

Johnston, I.M. 1936. A study of the Nolanaceae. Contrib. Gray Herb. 112:1-83.

Knapp, S. 2002. Tobacco to tomatoes: A phylogenetic perspective on fruit diversity in the Solanaceae. J. Expt. Bot. 53:2001-2022.

Mesa M.A. 1981. Nolanaceae. Flora Neotropica 26:1-197.

Mesa M.A. 1997. Nolanaceae de distribución Chileno-Peruana: su status taxonómico. Bol. Mus. Nac. Hist. Nat. 46:23-32.

Mesa M.A., M. Muñoz-Schick, and R. Pinto B. 1998. Presencia de Nolana adansonii (Roemer y Schultes) Johnst. y Nolana intonsa Johnst. (Nolanaceae) en el desierto costero de Iquique, Norte de Chile. Not. Men. Mus. Nac. Hist. Nat. 333:3-7.

Royal Horticultural Society. 1995. RHS colour chart. Royal Hort. Soc., London.

Rundel, P.W., M.O. Dillon, B. Palma, H. A. Mooney, S. L. Gulmon, and J. R. Ehleringer. 1991. The phytogeography and ecology of the coastal Atacama and Peruvian Deserts. Aliso 13:1-50.

Saunders, E.R. 1934. The history, origin and characters of certain interspecific hybrids in Nolana and their relation to Nolana paradoxa. J. Genet. 29:387-419.

Tago-Nakawaza, M. and M.O. Dillon. 1999-2000. Biogeografía y Evolución en el Clado Nolana (Solaneae-Solanaceae). Arnaldoa 6:81-116. 